\title{
Obstetric Outcomes of Twin Pregnancies in Japanese Women Aged 40 and Older
}

\author{
Shunji Suzuki
}

\begin{abstract}
Background: The aim of this study was to compare the obstetric outcomes of twin pregnancies between Japanese women aged $\geq 40$ years and their younger counterparts aged $25-29$.

Methods: This was a retrospective study of twin pregnancies managed at Japanese Red Cross Katsushika Maternity Hospital between 2002 and 2016. Women aged 40 and older at delivery $(n=117)$ were compared with women aged $25-29$ at delivery $(n=536)$.

Results: Although the women $\geq 40$ years old were more likely to have increased risks of HELLP (hemolytic, elevated liver enzymes and low platelet) syndrome and very low birth weight neonates, there were no measurable differences in obstetric outcomes such as hypertensive disorders, premature delivery and neonatal asphyxia between the two groups.
\end{abstract}

Conclusion: Advanced maternal age did not seem to affect obstetric outcomes in twin pregnancies seriously.

Keywords: Twin pregnancy; Age 40 or older; Obstetric outcomes

\section{Introduction}

Traditionally, advanced maternal age (AMA) and twin pregnancy are both independent risk factors for adverse obstetric outcomes with an increasing incidence of hypertensive disorders, cesarean birth and maternal and (or) newborn complications [1-6]; however, our subgroup analyses of twins in 2007 have found that AMA aged 35 years and over was not associated with increased risk for adverse outcomes [7]. In recent decades, the proportion of both twin and AMA births has increased due to the advances in assisted reproductive technology (ART) and the permission of two embryos transfer in patients of advanced age [8]. Although there have been a considerable number of studies concerning maternal and perinatal outcomes of singleton pregnancy in women older than 35 - 45

Manuscript submitted July 31, 2017, accepted August 14, 2017

Department of Obstetrics and Gynecology, Japanese Red Cross Katsushika Maternity Hospital, 5-11-12 Tateishi, Katsushika-ku, Tokyo 124-0012, Japan. Email: czg83542@mopera.ne.jp

doi: https://doi.org/10.14740/jocmr3148w years and those of twin pregnancy in women older than 35 years, those targeting of twin pregnancy in women of much older than 40 years are still limited [1-7, 9-13]. The aim of this study is to investigate maternal and neonatal outcomes in twins in Japanese women greater than 40 compared to their younger counterparts aged $25-29$.

\section{Materials and Methods}

The protocol for this study was approved by the Ethics Committee of the Japanese Red Cross Katsushika Maternity Hospital.

This was a retrospective study of twin pregnancies managed at Japanese Red Cross Katsushika Maternity Hospital between 2002 and 20016. Based on the study design of our previous study and recent studies in twin pregnancy, Japanese women 40 years and older at delivery ( $\mathrm{n}=117$ : AMA group) were compared with Japanese women aged 25 - 29 at delivery ( $\mathrm{n}=536$ : control group).

Data included antenatal data, gestational age at delivery, mode of delivery, birth weight, Apgar score at 1 and 5 min and postpartum hemorrhage requiring transfusion. In our institute, the guidelines for vaginal delivery of twin pregnancy are: 1) without severe complications such as twin-twin transfusion syndrome, 2) without history of previous cesarean deliveries, 3 ) vertex presentation of the first twin, 4) gestational age at delivery $\geq 33$ weeks, and 5) estimated birth weight of at least $1,500 \mathrm{~g}$ for each twin. In addition, we performed cesarean section for maternal request in cases of twin pregnancy.

Data are expressed as the number (percentage). SPSS Statistics software version 20 (IBM Corp., Armonk, NY, USA) was used for statistical analyses. A Chi-square test was used for categorical data, and a P-value $<0.05$ was considered significant. Logistic regression analysis was used to estimate odds ratios (ORs) and 95\% confidence intervals (CIs).

\section{Results}

Table 1 shows the maternal characteristics of this study. The women $\geq 40$ years old were more likely to have used ART ( $32 \%$ vs. $0 \%, \mathrm{P}<0.01)$. The rates of multiparous women and those with uterine myoma with a diameter of $4 \mathrm{~cm}$ or more in the AMA group are higher than those in the control group (multiparous: OR 2.43, 95\% CI $1.5-3.6, \mathrm{P}<0.01$; uterine myoma: OR 2.04, 95\% CI $1.1-3.8, \mathrm{P}=0.04)$. There were no 
Table 1. Maternal Characteristics of Twin Pregnancy in Women Aged 25 - 29 (Control) and $\geq 40$ Years (Advanced Age)

\begin{tabular}{|c|c|c|c|c|c|}
\hline & \multicolumn{2}{|c|}{ Control } & \multicolumn{2}{|c|}{ Advanced age } & \multirow{2}{*}{ P-value } \\
\hline & Number & $\%$ & Number & $\%$ & \\
\hline Total & 536 & & 117 & & \\
\hline \multicolumn{6}{|l|}{ Maternal age at delivery } \\
\hline Range & $25-29$ & & $40-45$ & & \\
\hline Average & $27.9 \pm 0.8$ & & $41.9 \pm 0.7$ & & \\
\hline Nulliparous & 358 & 67 & 53 & 45 & $<0.01$ \\
\hline Maternal height & $156 \pm 6$ & & $157 \pm 7$ & & 0.68 \\
\hline Prepregnancy body mass index & $22.0 \pm 3.5$ & & $22.3 \pm 3.1$ & & 0.55 \\
\hline Body mass index at delivery & $27.5 \pm 3.7$ & & $27.3 \pm 3.5$ & & 0.48 \\
\hline In vitro fertilization & 0 & 0 & 38 & 32 & $<0.01$ \\
\hline Egg donor & 0 & 0 & 0 & 0 & 1 \\
\hline Fetal reduction & 0 & 0 & 1 & 1 & 0.18 \\
\hline Monochorionic twin pregnancy & 204 & 38 & 41 & 35 & 0.46 \\
\hline Chronic hypertension & 0 & 0 & 1 & 1 & 0.18 \\
\hline Pregestational diabetes & 0 & 0 & 0 & 0 & 1 \\
\hline Low-dose aspirin in pregnancy & 0 & 0 & 0 & 0 & 1 \\
\hline $\begin{array}{l}\text { Uterine myoma with a } \\
\text { diameter of } 4 \mathrm{~cm} \text { or more }\end{array}$ & 36 & 7 & 15 & 13 & 0.04 \\
\hline
\end{tabular}

Data are presented as number with percentage or mean \pm SD.

cases of egg donor and one case of fetal reduction.

Table 2 shows the maternal and neonatal outcomes. The difference in the incidence of hypertensive disorders between the two groups did not reach statistically significance $(\mathrm{P}=$ 0.09); however, the incidence of HELLP syndrome (hemolytic, elevated liver enzymes and low platelet syndrome) in the AMA group was higher than that in the control group (3\% vs. $0 \%, \mathrm{P}$ $<0.01)$. On the other hand, the incidence of preterm delivery at $<32$ weeks in the AMA group was lower significantly than that in the control group (OR $0.107,95 \%$ CI $0.018-0.62$ ). The difference in the incidence of neonatal birth weight discordance $\geq 20 \%$ did not reach statistically significance $(P=0.53)$. However, the incidence of neonatal low birth weight in smaller twin in the AMA group was higher than that in the control group $(<1,500 \mathrm{~g}$ : OR $2.23,95 \%$ CI $1.2-4.2, \mathrm{P}=0.02 ;<2,500$ g: OR $2.68,95 \%$ CI $1.1-6.6, \mathrm{P}=0.04)$, while the incidence of neonatal low birth weight in larger twin in the AMA group was lower than that in the control group $(<1,500 \mathrm{~g}$ : OR 0.236 , $95 \%$ CI $0.088-0.63, \mathrm{P}<0.01 ;<2,500$ g: OR $0.366,95 \% \mathrm{CI}$ $0.23-0.58, \mathrm{P}<0.01)$.

\section{Discussion}

In this study, it was found that AMA Japanese women were more likely to have used ART for twin pregnancies and were complicated by uterine myoma. These findings are supported by some previous studies [1-13]. In our earlier study, the rate of cesarean delivery in AMA women was higher than that in younger women [7]; however, in the current study, the differ- ence in the rate of cesarean delivery did not reach statistical significance. This may be due to the recent dramatic increase in the overall cesarean delivery rate of twin pregnancies [14, 15]. The increase has been supposed to be due to physician counseling and maternal request for elective cesarean delivery to avoid perinatal asphyxia especially in the second twin and/ or combined vaginal-cesarean delivery [16-18].

Based on the current study, AMA did not seem to be a risk factor for the development of hypertensive disorders or gestational diabetes in twin pregnancy. It may support our previous study [7]; however, the current results may be against a recent study indicating the high rates of cesarean delivery, preeclampsia and gestational diabetes in twin pregnancies in women 45 years of age or older [3]. In some earlier studies in twin pregnancies, an increased incidence of preeclampsia has been reported to be associated with nulliparity $[19,20]$. In this study, the lower rate of nulliparous women in the AMA group may be associated with the similar rate of hypertensive disorders between the two groups. Instead, severe cases of hypertensive disorders such as HELLP syndrome might be more common in AMA women with twin pregnancy. A recent large study by Premru-Srsen et al [21] shows that nulliparity is also significantly associated with twin very preterm birth.

In this study, the rate of very low birth weight neonates in the AMA group was higher than that in the control group. Based on the current results of the neonatal birth weight, the incidence of negligible birth weight discordance between the twins seemed to be more frequently in AMA women than that in the control. The reason leading to the observation is not clear. One possible reason may be the higher rate of uterine 
Table 2. Obstetric Outcomes of Twin Pregnancy in Women Aged 25 - 29 (Control) and $\geq 40$ Years (Advanced Age)

\begin{tabular}{|c|c|c|c|c|c|}
\hline & \multicolumn{2}{|c|}{ Control } & \multicolumn{2}{|c|}{ Advanced age } & \multirow{2}{*}{ P-value } \\
\hline & Number & $\%$ & Number & $\%$ & \\
\hline Total & 536 & & 117 & & \\
\hline \multicolumn{6}{|l|}{ Gestational age at delivery } \\
\hline$<28$ weeks & 12 & 2 & 0 & 0 & 0.14 \\
\hline$<32$ weeks & 40 & 7 & 1 & 1 & 0.01 \\
\hline$<34$ weeks & 72 & 13 & 16 & 14 & 0.95 \\
\hline$<37$ weeks & 303 & 57 & 75 & 64 & 0.15 \\
\hline \multicolumn{6}{|l|}{ Cesarean delivery } \\
\hline Elective & 351 & 65 & 80 & 68 & 0.59 \\
\hline After labor & $42 / 185$ & 23 & $11 / 37$ & 30 & 0.40 \\
\hline Hypertensive disorder & 48 & 9 & $17 / 116$ & 15 & 0.09 \\
\hline HELLP syndrome & 0 & 0 & 3 & 3 & $<0.01$ \\
\hline Gestational diabetes & 8 & 1 & 0 & 0 & 0.36 \\
\hline Placental abruption & 6 & 1 & 1 & 1 & 1.00 \\
\hline Placenta previa & 1 & 0 & 0 & 0 & 1.00 \\
\hline Either twin fetal demise & 0 & 0 & 0 & 0 & 1.00 \\
\hline At 12 - 21 weeks & 0 & 0 & 0 & 0 & 1.00 \\
\hline At $\geq 22$ weeks & 3 & 1 & 0 & 0 & 0.96 \\
\hline \multicolumn{6}{|l|}{ Birth weight of smaller twin } \\
\hline$<1,500 \mathrm{~g}$ & $33 / 533$ & 6 & 15 & 13 & 0.02 \\
\hline$<2,500 \mathrm{~g}$ & $476 / 533$ & 88 & 112 & 96 & 0.04 \\
\hline \multicolumn{6}{|l|}{ Birth weight of larger twin } \\
\hline$<1,500 \mathrm{~g}$ & 70 & 13 & 4 & 3 & $<0.01$ \\
\hline$<2,500 \mathrm{~g}$ & 461 & 86 & 81 & 69 & $<0.01$ \\
\hline Birth weight discordance $\geq 20 \%$ & 33 & 6 & 9 & 8 & 0.53 \\
\hline \multicolumn{6}{|l|}{ Neonatal outcomes of first twin } \\
\hline Apgar score at $1 \min <7$ & 18 & 3 & 0 & 0 & 0.06 \\
\hline Apgar score at $5 \min <7$ & 1 & 0 & 0 & 0 & 1.00 \\
\hline \multicolumn{6}{|l|}{ Neonatal outcomes of first twin } \\
\hline Apgar score at $1 \mathrm{~min}<7$ & $33 / 533$ & 16 & 2 & 2 & 0.07 \\
\hline Apgar score at $5 \min <7$ & $1 / 533$ & 0 & 0 & 0 & 1.00 \\
\hline $\begin{array}{l}\text { Postpartum hemorrhage } \\
\text { requiring transfusion }\end{array}$ & 8 & 2 & 4 & 4 & 0.24 \\
\hline
\end{tabular}

Data are presented as number with percentage. HELLP: hemolytic, elevated liver enzymes and low platelet.

myoma in AMA women. The presence of myoma might contribute to the development of difference in fetal blood flow distribution between the twins associated with the irregularities of the uterine cavity due to myoma.

We understand that there are some limitations in this study. The current results were obtained from a small sample size. In addition, we could not examine the influence of very advanced maternal age ( $>45$ years old), egg donation, and/or nulliparity on obstetric outcomes in twin pregnancies. Donor egg has been a well-known risk factor for the development of preeclampsia [22]. In Japan, legislation for egg donation has not been in place and social consensus in egg donation or fetal reduction has not been well acquired. Thus, a further study will be needed with a large sample size.

In conclusion, advanced maternal age of $\geq 40$ years did not seem to be associated with serious adverse obstetric outcomes in twin pregnancies.

\section{Competing Interests}

The author has declared that no competing interests exist. 


\section{References}

1. Haydon M, Gaffaney CL, Saul L, Rumney P, Ghamsary $\mathrm{M}$, Lagrew D. Twin pregnancies in women greater than 40 years of age. Could advanced age improve obstetric outcome? Am J Obstet Gynecol. 2006;195:S108.

2. McLennan AS, Gyamfi-Bannerman $\mathrm{C}$, Ananth CV, Wright JD, Siddiq Z, D'Alton ME, Friedman AM. The role of maternal age in twin pregnancy outcomes. Am J Obstet Gynecol. 2017;217(1): 80.e1-80.e8.

3. Gerber RS, Fields JC, Barberio AL, Bodenlos K, Fox NS. Outcomes of Twin Pregnancies in Women 45 Years of Age or Older. Obstet Gynecol. 2017;129(5):827-830.

4. Suzuki S, Miyake H. Perinatal outcomes of elderly primiparous dichorionic twin pregnancies conceived by in vitro fertilization compared with those conceived spontaneously. Arch Gynecol Obstet. 2010;281(1):87-90.

5. Prapas N, Kalogiannidis I, Prapas I, Xiromeritis P, Karagiannidis A, Makedos G. Twin gestation in older women: antepartum, intrapartum complications, and perinatal outcomes. Arch Gynecol Obstet. 2006;273(5):293-297.

6. Zhang J, Meikle S, Grainger DA, Trumble A. Multifetal pregnancy in older women and perinatal outcomes. Fertil Steril. 2002;78(3):562-568.

7. Suzuki S, Igarashi M. Risk factors for preeclampsia in Japanese twin pregnancies: comparison with those in singleton pregnancies. Arch Gynecol Obstet. 2009;280(3):389393.

8. Hayashi M, Satoh S, Matsuda Y, Nakai A. The effect of single embryo transfer on perinatal outcomes in Japan. Int J Med Sci. 2015;12(1):57-62.

9. Cleary-Goldman J, Malone FD, Vidaver J, Ball RH, Nyberg DA, Comstock CH, Saade GR, et al. Impact of maternal age on obstetric outcome. Obstet Gynecol. 2005;105(5 Pt 1):983-990.

10. Grotegut CA, Chisholm CA, Johnson LN, Brown HL, Heine RP, James AH. Medical and obstetric complications among pregnant women aged 45 and older. PLoS One. 2014;9(4):e96237.

11. Jahan MK, Shafiquzzaman M, Nahar K, Rahman M, Sultana N, Rahman MM, Begum R. Outcome of pregnancy in women 35 years of age and above. Mymensingh Med J. 2009;18(1):7-12.

12. Dietl A, Cupisti S, Beckmann MW, Schwab M, Zollner U. Pregnancy and obstetrical outcomes in women over 40 years of age. Geburtshilfe Frauenheilkd. 2015;75(8):827832.

13. Pawde AA, Kulkarni MP, Unni J. Pregnancy in women aged 35 years and above: a prospective observational study. J Obstet Gynaecol India. 2015;65(2):93-96.

14. Suzuki S, Nakata M. Factors associated with the recent increasing cesarean delivery rate at a Japanese perinatal center. ISRN Obstet Gynecol. 2013;2013:863282.

15. Suzuki S, Yamashita E, Inde Y, Hiraizumi Y, Satomi M. Increased rate of elective cesarean delivery and neonatal respiratory disorders in twin pregnancies. J Nippon Med Sch. 2010;77(2):93-96.

16. Borgida AF, Grabo H, Bobrowski RA, Ingardia CJ. Trends in mode of delivery of twins from 1999 to 2004. Obstet Gynecol. 2006;107:66S-67S.

17. Barrett JF. Delivery of the term twin. Best Pract Res Clin Obstet Gynaecol. 2004;18(4):625-630.

18. Kiely JL. The epidemiology of perinatal mortality in multiple births. Bull N Y Acad Med. 1990;66(6):618-637.

19. Lucovnik M, Blickstein I, Lasic M, Fabjan-Vodusek V, Brzan-Simenc G, Verdenik I, Tul N. Hypertensive disorders during monozygotic and dizygotic twin gestations: A population-based study. Hypertens Pregnancy. 2016;35(4):542-547.

20. Hehir MP, Breathnach FM, McAuliffe FM, Geary MP, Daly S, Higgins J, Hunter A, et al. Gestational hypertensive disease in twin pregnancy: Influence on outcomes in a large national prospective cohort. Aust N Z J Obstet Gynaecol. 2016;56(5):466-470.

21. Premru-Srsen T, Verdenik I, Steblovnik L, Ban-Frangez $\mathrm{H}$. Early prediction of spontaneous twin very preterm birth: a population based study 2002-2012. J Matern Fetal Neonatal Med. 2015;28(15):1784-1789.

22. Sekhon LH, Gerber RS, Rebarber A, Saltzman DH, Klauser CK, Gupta S, Fox NS. Effect of oocyte donation on pregnancy outcomes in in vitro fertilization twin gestations. Fertil Steril. 2014;101(5):1326-1330. 